\title{
POVERTY IN A RURAL AREA: THE ROLE OF THE SOCIAL WORKER
}

\section{Strydom, ME Tlhojane}

\section{PROBLEM STATEMENT}

There are many ways of looking at poverty. When poverty is measured in absolute terms, it refers to the financial means necessary for people to survive from day to day. The most basic measures of poverty in South Africa are the Minimum Living Level (MLL) and the Household Subsistence Level (HSL). They measure the amount of money necessary to provide a household (of six people) with the very basic necessities, including food, clothing, energy, washing, rent and transport to stay alive (Greeff, 2004:7). The Household Effective Level (HEL), which is the HSL plus 50\%, makes provision for some important items not covered by the HSL, namely tax, medical expenses, replacement of household equipment, education, recreation, personal care, pension and burial contributions. In 1999, for South Africa, that would have amounted to R800,00 per month (Greeff, 2004:7).

The problem with measures of absolute poverty is that they do not take into account the expectations, norms, values and customs of particular communities. While individuals may be able to stay alive on a certain income, they might feel disadvantaged within a particular situation. Measures of relative poverty consider people's perception of how poor they feel. They recognise that poverty is not only a physical phenomenon, but that it has economic, emotional and psychological dimensions (Greeff, 2004:8). In other words, poverty is not only about a shortage of money or lack of resources. It is about rights and relationships, about how people are treated and how they regard themselves, about powerlessness, exclusion and loss of dignity. Yet the lack of an adequate income is at heart of it (Church of England, 1985:11).

According to the HEL, almost half the South African population live in poverty (Knight, 2004:1; Herman, 2006:4). About 43\% of the population live on less than R250 per month (Netshitenzhe, 2007:3). The rural area contains 72\% of people who are poor (White Paper for Social Welfare, 1997). In per capita terms South Africa is an upper-middle-income country, but most South African households experience outright poverty or are vulnerable to poverty (May, 1998:55). In addition, the distribution of income and wealth in South Africa is among the most unequal in the world (Centre for Socio-Legal Studies, 2005:1; Van Tonder, 2003:19). The richest $20 \%$ earn $62,2 \%$ of the income, while the bottom $20 \%$ earn only $3,5 \%$ of the country's income (Pelser, 2006:2). This inequality is a problem because, for the country to prosper, it must utilise its entire population and use the full range of potential at its disposal (Greeff, 2004:11-12).

The underlying issue here is that the young South African democracy has thus far failed to deliver the full benefits of citizenship to large numbers of people, but conspicuously to local communities in the rural areas (De Jongh, 2002:442). The circumstances of the poor in the rural areas, and in particular in the case study under consideration here, are worsening in absolute and relative terms, because of a legacy of unequal access, control and distribution of resources. Many households still have unsatisfactory access to clean water, energy, health care and education (Centre for Socio-Legal Studies, 2005:1).

On numerous occasions the South African government has committed itself to enhancing social development so that all men and women, especially those living in poverty, may lead satisfied lives and contribute to the wellbeing of their families, their communities and humankind. On the part of the government, policies have been developed and poverty alleviation programmes 
have been established in various government departments and civil society organisations. For instance, the Department of Housing indicated that in the period 1994 to 1997 a total of 332,845 government-subsidised housing units had been built or were under construction, the Department of Water Affairs reported that up until 1997 more than one million people had been supplied with running water, the Department of Health provides free health care for young children and pregnant mothers, while the budget of the Department of Welfare can be regarded as a poverty-alleviation budget with all the grants and pensions that are paid out monthly (Fraser-Moleketi, 1997). Despite these efforts, the government has not been able to address the issue of poverty successfully (Gathiram, 2005:123).

While people living in poverty share a lack of command over resources, the causes of this lack of resources and the consequences of poverty itself vary between different groups that are poor. At the heart of a relative perspective on poverty is a concern with the ways in which those living in poverty are excluded from participating in society and from the benefits which accrue to the wealthier part of the population (Davidson \& Erskine, 1992:11). According to Townsend (1979:31), individuals, families and groups in the population can be said to be in poverty when they lack the resources to obtain the types of diet, participate in the activities and have the living conditions and amenities which are customary in the societies they belong to.

Economic growth and human development are linked and should enhance quality of life, and this is best achieved through advancing the capabilities of disadvantaged communities, households and individuals by improving their access to physical and social assets (Centre for Socio-Legal Studies, 2005:1). It is important for social workers to be capable of seeing poverty in its larger frame. Poverty cannot be understood solely in cold figures and clinical causal factors. There is an important qualitative side to poverty (Greeff, 2004:9). In their day-to-day work they are faced with the manifestations of poverty in the lives of individuals and families, and it might be difficult to avoid perceiving this poverty as a characteristic of the individual rather than a feature of the wider social and economic landscape that specific person inhabits (Davidson \& Erskine, 1992:11).

As a professional person, the social worker must seek an objective understanding of all relevant factors in the situation, which will encompass a broader view than the people involved. The social worker's concern is also with the welfare of others in the immediate environment, such as family members and others interacting with those being helped. Seen from a preventive viewpoint, consideration must be given to the problems of all persons suffering from the same difficulties as those he/she is currently working with. Furthermore, he/she must be part of policy and planning groups involved in any situation and in the interest of the entire community (Mitchell, 1981:6). Although not the only orientation, the basic and primary orientation of the social worker is to understand the situation from the position and viewpoint of the people involved. To achieve a better fit between the individual and his environment, it becomes clear that social workers are required to help people directly and to involve themselves in measures with a view to change their environment. The energy, creativity and assets of the poor are key human and social resources. All of society needs to be involved in the struggle for social development (Raphern, 2005:1).

Social work is there to help the destitute and to assist them to emerge from their state of dependency and become empowered (Mitchell, 1981:8-9). Without help, these people will continue to lead unproductive and powerless lives.

The following questions arise from the above comments: 
- What is the nature of poverty in a rural area?

- What is the effect of poverty on families?

- What is the role of the social worker in helping poverty-stricken families?

\section{AIM AND OBJECTIVES OF THE RESEARCH}

\section{Aim}

To examine the nature and the effect of poverty on families in a rural area and to provide guidelines for helping poverty-stricken families.

\section{Objectives}

- To examine the nature of poverty in a rural area;

- To investigate the effect of poverty on these families;

- To provide social workers with guidelines for helping poverty-stricken families.

\section{RESEARCH METHODOLOGY}

According to Neuman (2003:68), methodology refers to the techniques a particular discipline applies to manipulate data and acquire knowledge. The method of research in this study consisted of a literature study and an empirical survey.

\section{Research design}

According to Grinnell (2001:547), a research design is a plan which includes every aspect of a proposed research study from the conceptualisation of the problem right through to the dissemination of findings. The researchers found the quantitative descriptive (survey) design to be appropriate for this study (Fouché \& De Vos, 2005:133), because by means of this design and by utilising the questionnaire, they were able to unearth the knowledge, perceptions and attitudes of the research participants regarding poverty.

\section{Sampling}

Grinnell and Williams (1990:127) point out that a sample size of 10\% of the population is sufficient to provide reasonable control over sampling error. A sample was drawn from Modimola village in Mafikeng, North-West Province. For this study the population was the village consisting of 340 houses, while 40 families comprised the sample. Systematic sampling was used in this study. Strydom and De Vos (1998:197) emphasise that, in this type of sampling, only the first case is selected randomly and all the subsequent cases according to a particular interval - selecting each $n^{\text {th }}$ item, where $n$ is known as the sample interval. The researchers included every eighth house (n) in the village, starting at the first house in the first row.

\section{Measuring instrument}

Survey research was used in this study. During personal interviews with the heads of households, data were collected. The schedule was of a self-developed nature after having studied schedules in similar studies (Engelbrecht, 1997:269; Nkuna, 2001:321; Strydom, 2002:395).

The researchers constructed the data so that they could be computer processed in numerical form. The Statistical Consultation Services of the Potchefstroom Campus of the North-West University, utilising the programme known as The SAS System for Windows Release 9.2 TS 
Level 1 MO (SAS Institute, 2005), analysed the data. The limited qualitative data processing was done by hand by identifying themes and recurring ideas and patterns or beliefs

\section{Procedure}

The researchers did the following:

- Consulted with the headman of the village in order to obtain permission to conduct the research study;

- Compiled the schedule in both English and Setswana;

- Tested the schedule with three people who were not included in the sample with the purpose of maximising the level of reliability and validity of the instrument;

- Obtained consent from the 40 respondents in the village to complete the questionnaires.

\section{Ethical issues}

Grasso and Epstein (1992:118) describe social work ethics as those principles that are intended to define rights and responsibilities of the researchers and practitioners in social work in their relationship with one another and with other parties, including employers, research subjects, clients and students.

In this study the following aspects were considered:

- Harm to respondents

Strydom (1998:25) holds that the researcher must, within reasonable limits, protect subjects against any form of physical discomfort which may emerge from the research project. In this study the researcher thoroughly informed the respondents in advance regarding the purpose and nature of the investigation.

- Informed consent

In this study the issue of informed consent was regarded as important, and consent from the residents in the village was obtained for completing the schedule. It was important for them to realise that the research would lead to the development of strategies that would also be beneficial to them in the long run.

- Violation of privacy

Singleton, Straits, Straits and McAllister (1988:454) define the right to privacy as the individual's right to decide when, where, to whom and to what extent his or her attitudes, beliefs and behaviours will return to the former condition. In this study the researchers respected each respondent's right to privacy by ensuring that the schedule was completed in the seclusion of their homes.

- Voluntary participation

In this study the respondents were not forced to participate. The participants were simply regarded as volunteers. They knew that they had a choice to participate and could withdraw at any stage (Creswell, 2003:64).

\section{- Confidentiality}

In this study the issue of confidentiality was considered with the intention of protecting the privacy of the respondents. All the information that deserved to be treated confidentially was dealt with accordingly. No identification particulars were required. 
Ethical permission was granted by the Ethics Committee of the Potchefstroom Campus of the North-West University, project number 05K09.

\section{RESULTS}

The empirical data were organised in accordance with the schedule and will be discussed below.

\section{IDENTIFYING PARTICULARS}

\section{Age of respondents}

TABLE 1

AGE OF RESPONDENTS

\begin{tabular}{|l|c|c|c|}
\hline AGE OF RESPONDENTS & FEMALE & MALE & TOTAL \\
\hline $31-35$ & 6 & 3 & $9(22,5 \%)$ \\
\hline $36-40$ & 2 & 4 & $6(15 \%)$ \\
\hline $41-45$ & 3 & 5 & $8(20 \%)$ \\
\hline $46-50$ & 6 & 3 & $9(22,5 \%)$ \\
\hline $51-55$ & 5 & 3 & $8(20 \%)$ \\
\hline TOTAL & $\mathbf{2 2}$ & $\mathbf{1 8}$ & $\mathbf{4 0}(\mathbf{1 0 0 \%})$ \\
\hline
\end{tabular}

The age of the respondents varied from 31 to 55 years. There were more female respondents, because the men were mostly out job hunting or visiting.

\section{Language of respondents}

All the respondents were Setswana-speaking. This could be expected, since the majority of inhabitants in the North-West Province are Setswana-speaking.

Marital status of the heads of households

TABLE 2

MARITAL STATUS

\begin{tabular}{|c|c|c|c|c|c|}
\hline MARRIED & $\begin{array}{c}\text { DIVORCED / } \\
\text { SEPARATED }\end{array}$ & $\begin{array}{c}\text { LIVING } \\
\text { TOGETHER }\end{array}$ & WIDOWED & $\begin{array}{c}\text { NEVER } \\
\text { MARRIED }\end{array}$ & TOTAL \\
\hline $9(22,5 \%)$ & $1(2,5 \%)$ & $7(17,5 \%)$ & $6(15 \%)$ & $17(42,5 \%)$ & $\mathbf{4 0}(\mathbf{1 0 0 \% )}$ \\
\hline
\end{tabular}

Although only nine of the heads of households were married, the households functioned as a family. Thomlison (2002:4) remarks the following in this regard: "Families are made up of people who have a common history, experience a degree of emotional bonding, and engage in shared goals and activities." In other words, the family of today is not always biologically related or legally bound. This could lead to men having other relationships and not taking their paternal responsibilities seriously, because they are not legally obliged to care for their families. 
Level of education of heads of household

TABLE 3

LEVEL OF EDUCATION

\begin{tabular}{|l|c|}
\hline STATEMENT & HEAD OF HOUSEHOLD \\
\hline Never attended school & $20(50 \%)$ \\
\hline Grade 1-4 & $17(42,5 \%)$ \\
\hline Grade 5-8 & $3(7,5 \%)$ \\
\hline TOTAL & $\mathbf{4 0}(\mathbf{1 0 0 \%})$ \\
\hline
\end{tabular}

From the table it is clear that most of the heads of households have a low level of education, with 50\% never having attended school. This could be attributed to the schooling system before 1994, when schooling was not compulsory and very few schools were built in deep rural areas such as Modimola village.

Potgieter (1998:68) states that illiteracy is a difficult concept to define and that people use different criteria for its measurement. Some authors use six years of formal schooling as an indicator of literacy. Others see differences in educational systems as well as differences between schools in a single system as factors that influence the quality of education and eventually the literacy level (Mostert \& Lotter, 1990:14). It could thus be deduced that the majority of the respondents were illiterate.

Illiteracy is much higher in rural areas of South Africa and plays an important role in poverty and low level of entrepreneurship (Bernstein \& Gray, 1997:114). According to the Green Paper on population policy (1995), an estimated $50 \%$ of the rural population are illiterate, compared to $38 \%$ in urban areas (South African Communication Service, 1996:317).

Households with poorly educated household heads have a far higher incidence of poverty than those with better educated household heads (Whiteford, Posel \& Kelatwang, 1995:8). This is also true of the households in Modimola village.

\section{LIVING CONDITIONS}

\section{Basic services in house}

TABLE 4

BASIC SERVICES

\begin{tabular}{|l|c|c|c|}
\hline \multicolumn{1}{|c|}{ STATEMENT } & YES & NO & TOTAL \\
\hline Has electricity & $31(77,50 \%)$ & $9(22,50 \%)$ & $40(100 \%)$ \\
\hline Has running water in house & $0(0 \%)$ & $40(100 \%)$ & $40(100 \%)$ \\
\hline
\end{tabular}

The majority of households have electricity, which compares well with the rest of the SA population. Statistics South Africa found that seven out of ten households in South Africa have electricity (Van Eeden, 2003:15).

None of the households has access to clear running water in their houses. Approximately 8 million people in South Africa have no access to clear running water (Wyngaard, 2007:5), while 15 million people in the country have no access to a modern form of sanitation (Tempelhoff, 2006:5). 
South African Communication Service (1996:84) states that $80 \%$ of the world's diseases and sicknesses (cholera, diarrhoea, polio and typhus) are due to poor water supply and insufficient or non-existent sanitation facilities. This is underlined by the World Health Organisation (WHO), which believes that the number of water taps per 1000 of a population is a more meaningful health indicator than the number of hospital beds that are available (Bradley, 1987:84). Some of the inhabitants also mentioned that they suffer from diarrhoea.

\section{Housing}

Of the total number of respondents, all (100\%) live in their own houses, and none are renting. Most houses are built of mud, which means they are not very strong. Most of the houses consist of two rooms.

The average number of people sharing the house was six. The houses were overcrowded, because family members are mostly unemployed and are unable to extend their houses to accommodate additional members. The physical, psychological and social functioning of the family can be negatively affected by overcrowding. According to Schoeman (1979:113-116) .overcrowding can lead to a lack of privacy, causing frustration and conflict. Where children are forced to share rooms with adults they may witness sexual acts. Children can also sometimes take to the streets to get away from their overcrowded houses (Bezuidenhout, 1998:161).

In 1993 the backlog in respect of housing in South Africa was estimated to be in the region of one-and-a-half million units, of which $24 \%$ represented the needs of the African population. Many more people ( 1 million) are housed in hostels that need urgent upgrading and redevelopment. In a 1995 publication of the South African Institute for Race Relations, the estimate for informal houses rose to 4,5 million units, of which nearly 3 million were located in rural areas (South African Institute for Race Relations, 1994:323-350). Although the inhabitants of the village had to live in primitive houses which were not very strong, the houses belonged to them personally.

\section{Household appliances}

TABLE 5

HOUSEHOLD APPLIANCES

\begin{tabular}{|l|c|c|c|}
\hline STATEMENT & YES & NO & TOTAL \\
\hline Have radios & $6(15 \%)$ & $34(85 \%)$ & $40(100 \%)$ \\
\hline Have televisions & $2(5 \%)$ & $38(95 \%)$ & $40(100 \%)$ \\
\hline Have fridges & $0(0 \%)$ & $40(100 \%)$ & $40(100 \%)$ \\
\hline Have stoves & $2(5 \%)$ & $38(95 \%)$ & $40(100 \%)$ \\
\hline Have washing machines & $0(0 \%)$ & $40(100 \%)$ & $40(100 \%)$ \\
\hline Have bicycles & $1(2,5 \%)$ & $39(97,50 \%)$ & $40(100 \%)$ \\
\hline Have motorcars & $0(0 \%)$ & $40(100 \%)$ & $40(100 \%)$ \\
\hline Have donkey carts & $0(0 \%)$ & $40(100 \%)$ & $40(100 \%)$ \\
\hline
\end{tabular}

From the table above, it is clear that only a very small percentage own any household appliances. They also have no means of transport of their own. This is a sign of poverty, seeing that Statistics South Africa points out that $73 \%$ of South Africans own radios, 53,8\% have television sets and 51,2\% have refrigerators (Van Eeden, 2003:15). 


\section{HOUSEHOLD INCOME}

\section{Employment of the heads of households}

In the research group, $100 \%$ of the heads of households are unemployed.

Poverty has a strong employment dimension (Fraser-Moleketi, 1997). Job creation is critical in most economies of the world, but particularly so in South Africa where unemployment is increasing. In South Africa, with the government's preference for free market economic policies, an estimated 1.6 million sustainable jobs have been created between 1995 and 2002. This growth has, however, not matched the growth of the labour force during the same period (i.e. the number of persons who have entered the job market), which is estimated at more than 5 million. The net result is that, between 1995 and 2002, unemployment in South Africa increased from approximately 30\% to 40\% (Le Bruyns \& Pauw, 2004:202-203; Van Tonder, 2003:19).

According to Statistics South Africa, 50,2\% of the Black population are unemployed (Van Eeden, 2003:19). Black women and youths have been identified as major at-risk groups among the unemployed. It is especially the rural communities that suffer from high levels of unemployment. The rural unemployed usually move to urban areas out of desperation and are then faced with a far worse situation, rife with violence and crime (Potgieter, 1998:66).

Many see self-employment as the driving force of economic growth in developing countries, since it has brought about significant growth in developed countries. In the United States, for instance, more or less one in seven of the working population is self-employed. The South African employment growth is typical of a developing country in that growth in selfemployment has been 15\% per annum since 1991 (Roodt, 2005:18-19). According to the latest global entrepreneurship monitor, South Africa has fewer entrepreneurs than most developing countries (Janse van Vuuren, 2007:5).

However, self-employment is difficult. There is strong competition in most industries and satisfying the needs of clients demands a sophisticated entrepreneur. As entrepreneurs of the future increasingly move into higher-value service firms, they will also have to attain higher levels of education and skills to be able to interact with foreign suppliers and customers, if they are to succeed. Entrepreneurs should thus be more globally focused, better educated and more focused on service delivery. South Africa cannot afford to have a high failure rate among the self-employed, as one of the tasks ("jobs") of the self-employed is to create job opportunities for others (Roodt, 2005:18-19).

In a village with no proper infra-structure self-employment becomes essential. It is, however, necessary for opportunities to be provided to the inhabitants to make this possible.

\section{Means of income}

TABLE 6

MEANS OF INCOME

\begin{tabular}{|l|c|c|c|}
\hline STATEMENT & YES & NO & TOTAL \\
\hline Child support grant & $17(42,50 \%)$ & $23(57,50 \%)$ & $40(100 \%)$ \\
\hline Social pension & $9(28,50 \%)$ & $31(71,50 \%)$ & $40(100 \%)$ \\
\hline Disability grant & $2(5,00 \%)$ & $38(95,00 \%)$ & $40(100 \%)$ \\
\hline Foster care & $1(2,50 \%)$ & $39(97,50 \%)$ & $40(100 \%)$ \\
\hline Maintenance grant & $20(50,00 \%)$ & $20(50,00 \%)$ & $40(100 \%)$ \\
\hline
\end{tabular}

According to the information in the table above, most of the households receive grants. 
According to Statistics South Africa, 12 million people in South Africa receive social grants or pensions (De Lange, 2006b:2; Wyngaard, 2007:5). Approximately 25\% of the population of the North-West Province receive grants (Gerber, 2005:4). Both the Deputy President and the Minister of Finance have questioned the sustainability of these grants (De Lange, 2006b:2; 2006a:3).

The amounts of the grants for 2007 are as follows:

$\begin{array}{ll}\text { Old Age Grant } & \text { R870.00 } \\ \text { Disability Grant } & \text { R870.00 } \\ \text { Foster Child Grant } & \text { R620.00 } \\ \text { Care Dependency Grant } & \text { R870.00 } \\ \text { Child Support Grant } & \text { R200.00 }\end{array}$

It is the responsibility of the parents to see to it that the necessary means are provided to support the family adequately (Rossouw, 1999:61). Financial stability means that a sufficient income is sustained, which in turn ensures that the basic needs such as food, shelter and clothing are satisfied. If the parents are unable to support the family system financially, this will usually mean that the living standard drops. Normally this is accompanied by a possible shortage of food, housing, medical care and stronger dependence on others (South African Council for Social Work, 1997:136). Poverty is seen as a contributing factor to social disorganisation, therefore unfavourable economic and social circumstances can lead to delinquent behaviour (Gibson-Cline, 2000:221).

\section{Feeding scheme}

The majority of the people $38(95,00 \%)$ do not belong to any formal feeding schemes. However, the children are provided with bread and soup at their schools on a daily basis. In South Africa 4.6 million children are now included in the government feeding schemes at school (Malan, 2006:20).

\section{Vegetable garden}

None of the respondents has a vegetable garden because there is insufficient water. A food garden could have helped in generating income.

\section{Basic needs}

Respondents mentioned that they are unable to meet their basic needs due to a lack of employment opportunities. In the village the respondents reported that they always go hungry because of a lack of food. Respondents indicated that their daily food is porridge and wild vegetable (morogo). They occasionally eat bread and milk.

\section{EFFECT OF POVERTY ON THE HOUSEHOLD}

The respondents were asked what the effect of poverty on their households was. The following comments were received:

- "We have no transport."

- "We have no money to buy clothes."

- "We cannot eat healthy food."

- "We are malnourished."

- "Because of hunger we cannot think straight." 
- "We feel useless, helpless, demotivated and unsure about the future due to few job opportunities and a lack of skills in starting projects."

- "We are frustrated and devastated."

- "We are easily infected by diseases, especially tuberculosis."

- "We are dependent on others for handouts."

- "The children are unhappy because they lack basic essentials and have no toys."

- "The children find it difficult to concentrate at school."

- "The family members are separated as some have to look for work in far off places."

- "We have marital problems."

- "There is violence in the community."

From the comments above it is clear that poverty has a negative effect on the families. These comments are an expression of their helplessness and powerlessness. Scarce resources and a lack of facilities are common features of rural communities (Simpson, 2003:156).

\section{ALLEVIATION OF POVERTY}

The respondents were asked about ways of alleviating poverty. The following comments were received:

- "People should engage in existing projects."

- "People should start their own projects by forming support groups."

- "People should go to the cities to look for work."

- "People should better their knowledge and skills by attending workshops and other training opportunities."

- "The government should give people wages to assist them in finding work."

- "The government should give children bursaries."

- "It should be possible for the residents to sell their products, such as

- egetables and knitted garments to nearby villages, by liaising with relevant government departments that could assist in marketing products."

- "The products could be sold at pay points during pension days."

From the above-mentioned comments it is obvious that the families need assistance to alleviate their poverty. They mostly look to the government for assistance. 
TABLE 7

MEANS OF SOCIAL WORK SUPPORT HOUSEHOLDS RECEIVE AND WOULD LIKE TO RECEIVE

\begin{tabular}{|l|c|c|c|}
\hline \multicolumn{1}{|c|}{ STATEMENT } & $\begin{array}{c}\text { SUPPORT } \\
\text { RECEIVED }\end{array}$ & $\begin{array}{c}\text { WOULD } \\
\text { WELCOME } \\
\text { SUPPORT }\end{array}$ & TOTAL \\
\hline Regular visits from the social worker. & $3(2,63 \%)$ & $37(97,37 \%)$ & $40(100 \%)$ \\
\hline Counselling services. & $1(2,50 \%)$ & $39(97,50 \%)$ & $40(100 \%)$ \\
\hline $\begin{array}{l}\text { Providing life skills information, e.g. financial } \\
\text { management. }\end{array}$ & $6(15,00 \%)$ & $34(85 \%)$ & $40(100 \%)$ \\
\hline $\begin{array}{l}\text { Linking the community with relevant resources, e.g. } \\
\text { relevant and available departments. }\end{array}$ & $0(0 \%)$ & $40(100 \%)$ & $40(100 \%)$ \\
\hline Forming support groups. & $0(0 \%)$ & $40(100 \%)$ & $40(100 \%)$ \\
\hline $\begin{array}{l}\text { Helping them to engage in or start community } \\
\text { projects. }\end{array}$ & $0(0 \%)$ & $40(100 \%)$ & $40(100 \%)$ \\
\hline $\begin{array}{l}\text { Helping them to complete business plans for financial } \\
\text { assistance. }\end{array}$ & $0(0 \%)$ & $40(100 \%)$ & $40(100 \%)$ \\
\hline Referral system. & $0(0 \%)$ & $40(100 \%)$ & $40(100 \%)$ \\
\hline
\end{tabular}

According to the table above, the respondents presently receive little service from social workers. They would welcome all the services indicated in the table, as they felt that this would assist them in living a better life.

The Acting Deputy Director General of North West, K. Sehularo, said the North-West Province was in desperate need of skilled entrepreneurs to establish and run viable businesses. The importance of development of small business cannot be over-emphasised, and for historical reasons the majority of the people are not able to find employment in the market place. They live in hunger and poverty; therefore the development of thriving small businesses can go a long way towards alleviating these hardships (Sehularo, 2006:3). The social worker, with the necessary support from the government and private organisations, can help in this regard.

\section{DISCUSSION}

\section{THE NATURE OF POVERTY}

In terms of absolute and relative poverty, it is evident that most community members are poverty-stricken. Their level of education is very low and 50\% of household heads never attended school.

Their houses are overcrowded and not up to standard. They have no running water or sanitation. There are almost no basic appliances in the houses such as stoves, fridges, televisions and radios.

The research findings indicate that most of the people are unemployed. They derive their income mainly from grants. Because of the small income, they always go hungry and there are signs of malnutrition. 


\section{EFFECT OF POVERTY}

According to the research findings, it is evident that poverty causes problems. This is also supported by the literature of Schenck (2004:158-160) in which she asked social workers in the rural areas to name the problems. They mentioned HIV/AIDS, illiteracy, unemployment, ill health, malnutrition, alcohol and drug dependency, marital conflict, domestic violence and crime. HIV/AIDS makes them feel weak and isolated. Illiteracy leaves them uninformed, dependent and disadvantaged. Unemployment makes them feel depressed, worthless and helpless. Ill health and malnutrition make them prone to other diseases and unable to perform duties. Because they have no jobs and nothing to keep them busy, they end up abusing alcohol and drugs. Marital conflict and domestic violence are rife because they blame each other for their perilous circumstances. The crime rate is high because there are no recreational or entertainment facilities, and people have to steal to eat.

The families struggle to cope, because everything they get is from hand to mouth. They survive through handouts and grants. Children receive food from the feeding schemes at schools. Families are occasionally provided with food parcels from the government.

\section{MEANS OF SOCIAL WORK SUPPORT}

At present the community receives very little help from social workers. It is clear from their comments that they realise that the social worker can play an important role in assisting the community in living a better life.

\section{THE ROLE OF THE SOCIAL WORKER}

Social workers should identify those people who are especially vulnerable and ensure that their abilities and potential are developed and strengthened (Roux, 2002:116). In order to assist a client to reach his/her potential, while finding and implementing solutions to the problems, the social worker takes on a variety of interventive roles. The worker's interventive roles constitute the behaviour expected of the social worker by both the client and the social worker to accomplish objectives (Compton \& Galaway, 1999:309). In other words, social workers' roles are determined by client needs (Hoffman \& Sallee, 1994:76). Zastrow (2004:77-79) identifies the following social work roles:

\section{TABLE 8 \\ ROLES OF THE SOCIAL WORKER}

\begin{tabular}{|l|l|}
\hline \multicolumn{1}{|c|}{ Role } & \multicolumn{1}{c|}{ Description } \\
\hline Enabler & Articulates needs, clarifies and identifies problems \\
Broker & Links individuals and groups with the community \\
Advocate & An active, direct role, advocates for clients rights \\
Activist & Seeks change, shift in power, resources for disadvantaged groups \\
Mediator & Intervention in disputes, finds compromises, reconciles, reaches agreements: \\
& a neutral role \\
Negotiator & Conflict bargaining and compromise: mutually acceptable agreements \\
Teacher & Giving information, teaching adaptive skills, communicator \\
Initiator & Calls attention to a problem \\
Empowerer & Helps to increase strengths by improving circumstances \\
Coordinator & Brings components together in an organised manner \\
Researcher & Studies literature, evaluates outcome \\
Group facilitator & Leader of group activity \\
Public speaker & Informs regarding available resources, advocates new services \\
\hline
\end{tabular}

Zastrow (2004:77-79) 
The roles indicated above specifically relate to service rendering in poverty issues. The roles of broker, enabler, teacher, mediator, advocate and healer are discussed in more detail, especially with regard to the practical situation.

\section{Broker}

A social broker links the client with other community resources in order to accomplish the objectives. This requires a broad knowledge of community resources, so that the social worker can help a client find and use a needed resource (Compton \& Galaway, 1999:309). As a broker, the social worker must ensure that the community is provided with resources, mobilise communities and also identify and network in order to ensure that resources are responsive to the needs of the community (Spies, 2007:149). The social worker should liaise with relevant stakeholders, including the following departments and institutions:

- The Department of Water Affairs to assist with water supply for food gardens;

- The Department of Agriculture to provide seeds and advice in this respect;

- The Department of Labour to assist the youth to obtain job skills;

- The Department of Social Development to help the community members to develop business plans. People who are responsible for projects should be taught appropriate skills, such as fundraising, marketing, finance management and project management;

- The Department of Tourism to train members to become chefs, caterers or hotel managers;

- An institution that could initiate a needlework project. Articles could be made from old unused material such as a pillow case or an old shirt, a ball made from shopping bags, or patchwork. Men could make articles from wood or leather remnants;

- Flea markets in larger towns that could help the people sell their articles.

\section{Enabler}

In the enabler role, the social worker assists clients in finding the coping strengths and resources within themselves in order to produce the changes required by the objectives (Compton \& Galaway, 1999:31). The enabler's work is built on a helping relationship with client systems (Hoffman \& Sallee, 1994:86).

Anti-poverty strategies should involve the poor directly in finding solutions. The energy, creativity and assets of the poor are key human and social resources (Fraser-Moleketi, 1997). Together the members and the social worker look at the positive aspects in the community, such as intimacy and caring for each other, the awareness of each other's needs and the huge amount of time spent in each other's company because of a lack of job and recreational activities. The social worker should get the members to work collectively to achieve access to opportunities and entitlements (Gathiram, 2005:128). Efforts should be made with regard to improving the self-esteem of the members, strengthening leadership, and changing negative stereotypes such as "poor people are powerless and cannot do anything for themselves".

With the knowledge of community resources, social workers could assist religious and service groups with strategic plans. Plans must be closely tied to available resources (Hannah, 2006:15). Social workers also need to ensure that those people who are eligible for social security receive grants. But it is important that grants are not abused and that the money is spent wisely. The Minister of Social Development said that 500,000 people were currently being investigated for fraud with grants, 200,000 grants have been cancelled and 10,000 cases have been identified for prosecution (Du Toit, 2007:11). 


\section{Teacher}

In the teacher role the social worker provides clients with new information necessary for coping with problem situations, assisting clients in practising new behaviours or skills, or model alternative behaviour patterns. The enabler helps clients to mobilise existing resources, whereas the teacher introduces additional resources into client systems (Compton \& Galaway, 1999:311). Community members accept that social workers have more knowledge pertaining to possible solutions and are prepared to accept their advice (Simpson, 2003:157).

The social worker should present workshops during which the members are taught various skills and techniques, including life skills, surviving skills and values and norms. The workshops should also include sessions during which adults learn parenting skills and youths are taught to listen to and respect adults. Since many of the community members have no formal education, programmes will help them to feel better about themselves and enable them to do something more meaningful with their lives. Community members must be encouraged to engage in projects that are sustainable, such as market gardens and sewing groups. Some people felt that learning practical skills such as how to make patchwork blankets and design clothes would be useful, as people could apply them in income generating activities. Some representatives/delegation could be sent to attend courses, conferences or workshops on poverty in order to gain some knowledge so as to come and share ideas with other community members or to empower them with skills. Clubs for children and youth can also be initiated in order to keep them occupied and off the streets.

\section{Mediator}

Mediation involves efforts to resolve disputes between the client system and other persons or organisations. In the mediating role, the social worker assists clients and the other party to find common ground on which to resolve the conflict (Compton \& Galaway, 1999:311). The social worker should be a peacemaker between different parties, especially concerning the misuse of funds such as grants from the government or donations from outside. Efforts should be made to ensure that people become aware of the wider socio-political and economic context in which they live. They should be given information on the various policies and pieces of legislation that have been adopted to promote social change and how they can be used to benefit the poor (Gathiram, 2005:123, 128). This will help them to know not only their rights, but also their responsibilities. It will give them the confidence to take action for the sake of their own liberation (Gathiram, 2005:127).

\section{Advocate}

As an advocate, the social worker presents and argues the client's cause, when necessary, in order to accomplish the objectives. In mediation the effort is to secure resolution to a dispute through give and take on both sides; in advocacy the effort is to win for the client (Compton \& Galaway, 1999:312). This is especially true with regard to exemption of school fees, purchasing school uniforms and obtaining bursaries for studies.

The social worker should speak to the chief of the village on behalf of the community members concerning a small plot/land to develop a project. It is important for members to participate in committees in order for advocacy to be successful (Hannah, 2006:16).

\section{Healer}

It is the function of social work to identify needs and problems that affect the social functioning of people and facilitate actions that might resolve or minimise these. The purpose is to interrupt 
and prevent the development of social dysfunction by discovering harmful conditions in time and to develop strategies that can control and eliminate problems (Spies, 2007:148). The danger of prostitution, child neglect, domestic violence, HIV/AIDS and substance abuse are some of the issues that need to be identified and addressed.

\section{CONCLUSION}

In this study one of the objectives was to examine the nature of poverty in a rural area. It was clear that the inhabitants of Modimola village were very poor, taking into account their low level of education, income and living conditions.

The second objective was to investigate the effect of poverty on the families. According to the research findings, it was evident that poverty causes problems from malnutrition and ill health to marital problems and violence. In the community, resources such as clinics and shops are lacking. Also, very few job opportunities are available in the area. Because of a lack of water, they are unable to cultivate vegetable gardens. They also have no means to look for better jobs in other areas. They do not have any projects in the area. In other words, the people are not coping with their perilous situation and are not doing anything to help themselves.

The people need someone to guide them, because they feel hopeless and powerless. The social worker can fulfil the roles of broker, enabler, teacher, mediator, advocate and healer to help alleviate the poverty in the area. Involving the poor directly will contribute to a culture of accountability and will ensure that anti-poverty strategies are appropriate, workable and sustainable. The third objective was to provide guidelines to social workers to help povertystricken families. Guidelines were compiled from the literature and research findings.

By meeting the three objectives, the aim of the research study was reached, and the theoretical assumption that social workers are able to help a community to improve its circumstances and thus alleviate its poverty was proven correct. Eradicating poverty is essential to consolidate the gains of a new democracy and a precondition for social justice, peace and security.

\section{REFERENCES}

BERNSTEIN, A. \& GRAY, M. 1997. Social work: A beginner's text. Durban: Juta.

BEZUIDENHOUT, F.J. 1998. A reader on selected social issues. Pretoria: Van Schaik Publishers.

BRADLEY, M.F. 1987. Community health for student nurses. London: Balliere Tindall.

CENTRE FOR SOCIO-LEGAL STUDIES. 2005. Poverty and the environment. Johannesburg.

COMPTON, B.R. \& GALAWAY, B. 1999. Social work processes. New York: Brooks/Cole Publishing Company.

CRESWELL, J.W. 2003. Research design: Qualitative, quantitative and mixed methods approaches. London: Sage Publication.

CHURCH OF ENGLAND. 1985. Faith of the city. London: Church House.

DAVIDSON, R. \& ERSKINE, A. 1992. Poverty, deprivation and social work. London \& Philadelphia: Jessica Kingsley Publishers.

DE JONGH. M. 2002. No fixed abode: the poorest of the poor and elusive identities in rural South Africa. Journal of South African Studies, 28(2):441-460. 
DE LANGE, D. 2006a. Toelae vir armes is nodig, sê Skweyiya. Beeld, 10 November: 3.

DE LANGE, D. 2006b. Welsyn ruk handuit - Phumzile. Rapport, 14 December: 2.

DE VOS, A.S. (ed) 1998. Research at grass roots: a primer for the caring professions. Pretoria: Van Schaik Publishers.

DE VOS, A.S., STRYDOM, H., FOUCHE, C.B. \& DELPORT, C.S.L. 2005. Research at grass roots: for the social sciences and human service professions. Pretoria: Van Schaik Publishers.

DU TOIT, P. 2007. Mense lugtiger om toelaes bedrieglik te kry. Beeld, 17 February: 11.

ENGELBRECHT, E.L. 1997. Maatskaplikewerkhulpverlening aan multiprobleem-gesinne. Pretoria: University of Pretoria. (Dissertation - MA)

FRASER-MOLEKETI, G. 1997. Poverty and government. Available: http://general. rau.ac.za/aambeeld/november 1997/povertyandgov.htm. [Rev. 5 May 2005].

FOUCHÉ, C.B. \& DE VOS, A.S. 2005. Quantitative research designs. In: DE VOS, A.S., STRYDOM, H., FOUCHÉ, C.B. \& DELPORT, C.S.L. Research at grass roots: for the social science and human service professions. Pretoria: Van Schaik Publishers.

GATHIRAM, N. 2005. Poverty alleviation: the need for a knowledgeable, active and empowered civil society. Social Work/Maatskaplike Werk, 41(2):123-129.

GERBER, A. 2005. Kwart van NW ontvang pensioene. North-West Gazette, 19 April: 4.

GIBSON-CLINE, J. 2000. Youth and coping in twelve nations: surveys of 18-20 years old young people. New York: Routledge.

GREEFF, J. 2004. Introduction to Sociology: poverty and development. Cape Town: Oxford University Press.

GRASSO, A. \& EPSTEIN, I. 1992. Research utilization in the social services. New York: The Harworth Press.

GRINNELL, R.M. 2001. Social work research and evaluation: Qualitative and quantitative approaches. Itasca: F.E. Peacock Publishers.

GRINNELL, R.M. \& WILLIAMS, M. 1990. Research in social work: A primer. Itasca: F.E. Peacock Publishers.

HANNAH, G. 2006. Maintaining product-process balance in community antipoverty initiatives. Social Work, 51(1):9-16.

HERMAN, D. 2006. Half of SA live in poverty. Pretoria News, 13 June: 4.

HOFFMAN, K.S. \& SALLEE, A.L. 1994. Social work practice: Bridges to change. Toronto: Allyn \& Bacon.

JANSE VAN VUUREN, A. 2007. Die klein outjies raak agter in SA. Beeld, 9 February: 5.

KNIGHT, R. 2004. A decade of democracy: Economic Policy and Development in South Africa. Available: http://richardknight.homestead.com/files/sieconomicpolicy2004.htm [Rev. 2/1/2005].

LE BRUYNS, C. \& PAUW, C. 2004. Looking in two ways: Poverty in South Africa and its ecclesiological implications. Dutch Reformed Theological Journal, 45(2):202-213. 
MALAN, M. 2006. 81\% oorsese Suid Afrikaners. Rapport, 1 January:3.

MAY, J. 1998. Poverty and inequality in South Africa. Indicator South Africa, 15(2):53-58.

MITCHELL, W.A. 1981. Poverty and social work. Grahamstown: Rhodes University.

MOSTERT, W.P. \& LOTTER, J.M. 1990. South Africa's demographic future. Pretoria: Human Science Research Council.

NETSHITENZHE, J. 2007. Miljoene meer ontvang toelaes. Rapport, 24 June:3.

NEUMAN, W.L. 2003. Social research methods: Qualitative and quantitative approaches. Boston: Allyn \& Bacon.

NKUNA, S.J. 2001. Guidelines for social workers rendering services concerning child abuse. Pretoria: University of Pretoria (Thesis - PhD.).

PELSER, W. 2006. SA se gehalte van lewe neig glo agtertoe. Beeld, 10 November:2.

POTGIETER, M.C. 1998. The social work process: Development to empower people. South Africa: Prentice Hall (Pty) LTD.

RAPHERN, N. 2005. Magazine of diocese of highveld; poverty - South African greatest challenges. Johannesburg.

ROODT, J. 2005. Self-Employment and the required skills. Management Dynamics, 14(1):18-19.

ROSSOUW, L. 1999. Social work family focused intervention for juvenile re-offenders. Stellenbosch: University of Stellenbosch. (MA Thesis)

ROUX, A.A. 2002. Evaluering van 'n groepwerk-hulpverleningsprogram met MIVpositief/VIGS-pasiënte. Potchefstroom: PU vir CHO. (PhD Thesis)

SAS INSTITUTE. 2005. The SAS System for Windows Release 9.1 TS Level 1 MO. Cary, NC, USA: SAS Institute.

SCHENCK, C.J. 2004. Problems rural social workers experience. Social Work/Maatskaplike Werk, 40(2):158-171.

SCHOEMAN, J.H. 1979. Die taak van gemeenskapswerk in 'n swart stedelike gebied. Pretoria: UP. (DPhil Thesis)

SEHULARO, K. 2006. Business steps up skills. North West Independent, 15 February, 3.

SIMPSON, B. 2003. What do residents of informal settlements think social workers should do: voices from Bhambayi. SocialWork/Maatskaplike Werk, 39(2):149-160.

SINGLETON, R., STRAITS, B.C., STRAITS, M.M. \& McALLISTER, R.J. 1988. Approaches to social research. New York: Oxford University Press.

SOUTH AFRICA. 1997. White Paper for Social Welfare. Department of Welfare. Pretoria: Government Printers.

SOUTH AFRICAN COMMUNICATION SERVICE. 1996. S.A. Yearbook. Pretoria: Government Printer.

SOUTH AFRICAN COUNCIL FOR SOCIAL WORK. 1997. Social auxiliary work. Pretoria: Government Printer. 
SOUTH AFRICAN INSTITUTE FOR RACE RELATIONS. 1994. Race Relation Survey 1993/94. Johannesburg: SAIRR.

SPIES, M. 2007. The biopsychosocial factors influencing HIV/AIDS patient adherence to antiretroviral therapy (ART): A social work study. Pretoria: UP. (DPhil Thesis)

STRYDOM, C. 2002. Evaluation of an HIV/AIDS programme for students at a tertiary institution with emphasis on peer group involvement. Potchefstroom: $\mathrm{PU}$ for $\mathrm{CHE}(\mathrm{PhD}$ Thesis)

STRYDOM, H. 1998. Ethical aspects of research in the caring professions. In: DE VOS, A.S. (ed) Research at grass roots: A primer for the caring professions. Pretoria: Van Schaik Publishers.

STRYDOM, H. \& DE VOS, A.S. 1998. Sampling and sampling methods. In: DE VOS, A.S. (ed) Research at grass roots: A primer for the caring professions. Pretoria: Van Schaik Publishers.

TEMPELHOFF, E. 2006. Miljarde het nie toegang tot sanitasie. Beeld, 22 March: 5.

THOMLISON, B. 2002. Family assessment handbook. New York: Brooks/Cole.

TOWNSEND, P. 1979. Poverty in the United Kingdom: a survey of household resources and standards of living. London: Penguin.

VAN EEDEN, J. 2003. Een uit ses nie getel vir sensus. Rapport, 13 July: 15.

VAN TONDER, J. 2003. Gaping tussen ryk en arm rek en rek. Rapport, 28 December: 19.

WHITEFORD, A., POSEL, D. \& KELATWANG, T. 1995. A profile of poverty, inequality and human development. Pretoria: Human Science Research Council.

WHITE PAPER FOR SOCIAL WELFARE, 1997. See South Africa.

WYNGAARD, H. 2007. Ontleding van president se staatsrede in syfers. Beeld, 11 February: 5. ZASTROW, C. 2004. Introduction to social work and social welfare. New York: Thomson.

Corinne Strydom, Lecturer, School of Psycho-Social Behavioural Sciences: Division Social Work, Potchefstroom Campus of the North-West University; Ellen Tlhojane, social worker, Department of Social Development, North-West Province, South Africa. 